\title{
Critical Study Relevance of Act No. 10 of 2016 with Government Regulation No. 151 of 2000
}

\author{
Iva Amiroch ${ }^{1}$
}

\begin{abstract}
Regional Head Elections regulated in Act No. 10 Of 2016 and Government Regulation No. 151 of 2000. So it will be described how the normative study the relationship between the Act No. 10 of 2016 by Government Regulation No. 151 of 2000 and how the relevance of critical studies law OF No. 10 of 2016 with a norm of life in society. Normatively Act 10 of 2016 is higher position with Government Regulation No. 151 of 2000, which is in line with the principle of Lex Superiori Derogat Lex inferiori, namely the rule of law higher can cancel the legal regulations below or lower, in other words lower regulation becomes invalid if it is contrary to a higher rule thereon, it is necessary synchronization between legislation No. 10 of 2016, with the Government Regulation. The problematics arise when there is a Constitutional Court decision No. 42 / PUU-XIII / 2015 annul Article 7, paragraph 2 (g) of the Act No. 10 of 2016, however, the cancellation should also be seen from the law of life in society (Living Law).

Keywords: Regional Head Election; Norms; Law.
\end{abstract}

\section{Introduction}

Election is a means rule of the people to elect members of parliament, members of the provincial legislative council, the president and vice president, and to elect members of regional representatives implemented in a direct, public, free, confidential, honest and fair in the Republic of Indonesia based on Pancasila and Constitution of the Republic of Indonesia of 1945 . $^{2}$ Regional elections include election of governor and deputy governor, regent and deputy regent, and mayor and deputy mayor. The existence of regional elections is proof that Indonesia is a democratic country with a proven to hold elections by involving the people as one of determining the merits of the future life of the nation.

Regional elections regulated in Act No. 10 Of 2016 on the second amendment to Act No. 1 of 2015 Concerning Determination of Government Regulation in Lieu of Act No. 1 of 2014 About the election of governors, regents and mayors become the law. And supported by Government Regulation No. 151 of 2000 on the procedure for the Election, Validation, and Dismissal of Regional Head and Deputy Head of Region and some other regulations, such as the Election Law, the Law Commission and others.

In both these rules there is one chapter in the spotlight for the public ie articles that govern how the right to be the head of the area when a status of being an ex-convict contained in Article 7 paragraph 2 (g) of Act No. 10 Of 2016 About the Second Amendment Act No. 1 of 2015 concerning Determination of Government Regulation in Lieu of Act No. 1 of 2014 on the Election of governors, regents and mayors Being Act and in Article 2 of Government Regulation No. 151 of 2000 on the procedure for the Election, Validation, and Dismissal of Regional Head and Deputy Head. The status of prisoners for most people would have been taboo and is often regarded as the dregs of society and ostracized by the community,

\footnotetext{
${ }^{1}$ Student of Masters (S2) of Law Faculty of Law Unissula Semarang e-mail : ivaamiroch@gmail.com

${ }^{2}$ Article 1 of Act No. 7 of 2017 on General Election.
} 
However, despite the public's assessment of frequent bad against former status of a prisoner, in reality there are some couples who nominate themselves as prospective head region to follow the Regional Head Elections and some legitimately elected as regional head in the election, said to legitimately that if the pair regional head candidates with the most votes and was declared elected candidate and candidate representatives. ${ }^{3}$

The Constitutional Court (MK) to give a decision on July 9, 2015 No. 42 / PUU-XIII / 2015 to put forward a Judicial Review (Material Test) in Article 7 (g) the Act No. 8 of 2015 on the Amendment to Act No. 12015 Concerning Determination of Government Regulation in Lieu of Act No. 1 of 2014 On the Election of governors, regents and mayors. Which states that the article is inconsistent with the Constitution of the Republic of Indonesia Of 1945 which is conditional to the extent not understood excluded for ex-convicts openly and honestly told the public that concerned former prisoners and stated that the articles do not have binding legal. ${ }^{4}$ Post-decision of the Court certainly can be a controversy of its own among the public because it does not conform to the norm of living in society, there will be people who disagree but many others do not, because it can not be denied, the background of the inmates is a predicate that is quite negative in the eyes of society, regardless of guilt or the least one. From the description the authors formulate the problem of how relations between the normative studies in Act No. 10 Of 2016 With Regulation No. 151 of 2000 and how the critical study of the relevance of Act No. 10 in 2016 with the norms of living in society.

\section{Discussion}

\subsection{Normative Study of the Relationship Between Act No. 10 of 2016 by Government Regulation No. 151 of 2000.}

Unitary Republic of Indonesia shall be divided into provincial regions and areas of the province is divided into districts and municipalities, which each province, district, and the city has a local government, which is regulated in the Act. ${ }^{5}$ The Regional Government is the organizer of government affairs by the local government and legislature according to the principles of autonomy and duty of assistance to the principle of broad autonomy within the system and the principles of the Republic of Indonesia as stipulated in the Constitution of the Republic of Indonesia Of $1945 .{ }^{6}$ Regional autonomy is a right, authority, and duties of the autonomous regions to set up and manage their own affairs and interests of local communities in the system of the Republic of Indonesia. ${ }^{7}$

The elections is a sign that Indonesia is a country that is democratic by giving the voting rights entirely to the people to elect representatives directly and democratically. In carrying out democratic system in general elections held direct, public, free, confidential, honest and fair every five years. ${ }^{8}$ In the regional elections every citizen has an equal

\footnotetext{
${ }^{3}$ Article 107 of Act No. 10 Of 2016 on the second amendment to Act No. 1 of 2015 Concerning Determination of Government Regulation in Lieu of Act No. 1 of 2014 On the Election of governors, regents and mayors Become Law.

${ }^{4}$ Amar Constitutional Court Decision No. 42 / PUU-XIII / 2015.

${ }^{5}$ Article 18 paragraph 1 of the Act of 1945.

${ }^{6}$ General Provisions Article 1 paragraph 2 of Act No. 23 of 2014 on Regional Government.

${ }^{7}$ General Provisions Article 6, paragraph 2 of Act No. 23 of 2014 on Regional Government.

${ }^{8}$ Section 22E of the Act of 1945.
} 
opportunity to run as a candidate for governor, vice-governor, Candidate Regent and Vice Regent Candidate, and Candidate Mayor and Vice Mayor. ${ }^{9}$ With the requirements described above in Article 7, paragraph 2 of Act No. 10 of 2016 on the second amendment to Act No. 1 of 2015 Concerning Determination of Government Regulation in Lieu of Act No. 1 of 2014 On the Election of governors, regents and mayors become the law. One of the requirements of the most highlighted is Article 7, paragraph $2(\mathrm{~g})$, namely; Candidates for deputy regional head never be convicted by a court decision that has obtained permanent legal force or for ex-convict has openly and honestly told the public that concerned the former convict. However, these provisions have been broken by the Constitutional Court Decision No. 42 / PUU-XIII / 2015 states that in Article 7, paragraph 2 (g) of the Act No. 10 of 2016, contrary to the Constitution of the Republic of Indonesia Of 1945 conditionally exempt to the extent not meant for ex-convicts openly and honestly told the public that concerned former prisoners and stated that the articles do not have legally binding. Already it is apparent if Article 7, paragraph 2 (g) of the Act No. 10 of 2016 could no longer be applied see the decision given by the Constitutional Court which still allow former inmates ran as the regional head election,

The Constitutional Court is the state agency for handling the case in the public administration, in order to preserve the constitution and performance among institutions, as well as a correction of previous false experience problems posed by the dual interpretation of the constitution. ${ }^{10}$ The Constitutional Court is the State agency that has a special judicial functions to handle certain constitutional cases that are intended to preserve and interpret the constitution and as a means of controlling the implementation of state control and the balance of powers (Checks and Balances) state institutions. ${ }^{11}$

One of the powers of the Constitutional Court which is to hear at the first and last to have a final decision to test the law against the Constitution, and therefore the Act No. 10 of 2016 shall comply with the Constitutional Court's decision No. 42 / PUU-XIII / 2015 because the status of the position of the law under the Act of 1945.

In addition to Act No. 10 of 2016 there is also a Government Regulation (PP), which regulates the election ie Government Regulation No. 151 of 2000 on the procedure for the Election, Validation, and Dismissal of Regional Head and Deputy Head of Region, this rule is the regional head and deputy is the Governor, Regent / Mayor and his deputy. In chapter 2 is described requirements to become candidates for regional heads, one of which is contained in Article 2 (h), described herein if the vice-head of the region have never been imprisoned for a crime. ${ }^{12}$ Similar conditions proposed Article 7, paragraph 2 (g) of Act No. 10 of 2016 which states that the vice-head of the region never be convicted by a court decision that has obtained permanent legal force or for ex-convict has openly and

\footnotetext{
${ }^{9}$ Article 7, paragraph 1 of Act No. 10 of 2016 on the second amendment to Act No. 1 of 2015 Concerning Determination of Government Regulation in Lieu of Act No. 1 of 2014 On the Election of governors, regents and mayors Become Law.

${ }^{10}$ General Explanation of Act No. 04 Of 2014 regarding the determination of Government Regulation in Lieu of Act No. 1 of 2013 on the second amendment to Act No. 24 of 2003 on the Constitutional Court.

11 Ikhsan Rosyada Parhulutan Daulay, 2006, Mahkamah Konstitusi Memahami Keberadaanya Dalam Sistem Ketatanegaraan Indonesia, Rineka Cipta, Jakarta,p. 29.

12 Article 2 (h) of Government Regulation No. 151 of 2000 on the procedure for the Election, Validation, and Dismissal of Regional Head and Deputy Head of Region, which in this rule is the regional head and deputy is the Governor, Regent / Mayor and his deputy.
} 
honestly told that the relevant public is an ex-convict. But seeing the Constitutional Court Decision No. 42 / PUU-XIII / 2015 regarding the article, it can be considered a rule in the article can no longer be used.

Legislation recognized its existence and have binding legal force throughout ordered by legislation that is higher or established pursuant to the authority. ${ }^{13}$ The legal force of legislation in accordance with the hierarchy. While the type and hierarchy regulation consists of:

- Constitution of the Republic of Indonesia Of 1945;

- People's Consultative Assembly Decree;

- Law / Government Regulation in Lieu of Law;

- Government regulations;

- Presidential decree;

- Provincial Regulation, and

- Regulation of the Regency / City. ${ }^{14}$

The principle on which the enforceability of the legislation, namely the principle of Lex Superiori Derogat Lex Inferiori, namely the rule of law higher can cancel legal regulations below or lower, in other words the rules lesser become illegitimate when it conflicts with a higher regulation thereon in accordance with the hierarchy of legislation. ${ }^{15}$ On this basis it is clear if the rules are written in Government Regulation No. 151 of 2000 Article 2 letter $\mathrm{h}$ unenforceable again considering the hierarchical position of government regulation under the laws and regulations on top of that Act number 10 of 2016. In Article 7 paragraph 2 (g) also cannot be imposed again by the decision of the Constitutional Court Number 42 / PUU-XIII / 2015 on the rights of former convicts in the selection of candidates for Regional Head on condition candidates have announced to the public that is concerned never be convicted by verdict court that has obtained permanent legal force.

\subsection{Relevance Critical Study of Act No. 10 of 2016, With Norms The Life In The Society.}

Act No. 10 of 2016 on the second amendment to Act No. 1 of 2015 Concerning Determination of Government Regulation in Lieu of Act No. 1 of 2014 On the Election of governors, regents and mayors become law. In the Act stipulated how in regional elections in the elections, and most in the spotlight which is contained in Article 7 paragraph $2(\mathrm{~g})$ is one of the requirements to be a candidate in the elections stating that the vice-head of the region has never been a convicted under a court decision that has obtained permanent legal force or for ex-convict has openly and honestly told the public that concerned the former convict.

In carrying out its activities in the life of society, every human being or associations certainly have rules or the rules of life in society, to distinguish between what is good and not good to do and sometimes these norms have grown and grown in the absence of a rule that is written but it is binding in nature within the community. Some norms of life and organize relationships in society, namely the legal norms, religious norms, norms of decency and norms of decency. Norms (rule) is considered as something that is abstract

\footnotetext{
${ }^{13}$ Article 08, paragraph 2 of Act No. 12 of 2011 Concerning the Establishment Regulation Legislation.

${ }^{14}$ Article 07 of Act No. 12 of 2011 Concerning the Establishment Regulation Legislation.

${ }^{15}$ Yadiman, 2011, Tehnik Pembuatan Perundangan, Cetakan Pertama, Badan Geologi, p. 86-87.
} 
and can not be captured by the senses. The law, which is written in the legislation is manifestation of the norm, the rule is also manifested in the form of signs. ${ }^{16}$

Law is one of the norms of living in society. The law generally defined as the overall regulation or rules in a common life, the whole of conduct, which applies in a life together, which can be imposed with a sanction implementation. ${ }^{17}$ Whatever its name or function anything what was to be done by law remains apart from the legal sense as a system that is as a system of norms. ${ }^{18}$

Laws exist only to society, law is a rule that was created for their human / society, the law exists to change the irregularities that occurred in the community to get back to being better, and therefore in the creation of law, such as in the creation of legislation should adjust to community life, to be carried out and in accordance with the needs of today's society.

Law is a set of norms that regulate behavior in society, law as a guide must not conflict with religious norms, norms of decency and civility growing norm in society. Law in written form in the form of rules of law ranging from basic Act to local regulations and other rules. In the form of unwritten law may be customary law, morality, decency, and so forth, because the law basically can not stand alone without the support of other norms.

In accordance with rules governing legislation that rules the lower regulations must not conflict with the rules of the higher, as in stufenbau theory put forward by Hans Kelsen and developed by Hans Nawiasky which are then applied in the provision of rules of legislation. Stufenbau theory states that the legal system is a system in which the rule of stairs with a lower legal rules must be adhered to the rule of higher law.

According to Hans Kelsen legal norms are the rules, patterns or standards that need to be followed, the function is to govern the legal norms, authorize, allow, prohibit, and store of provisions. ${ }^{19}$ In addition to legal norms there are three norms longer live in a society that is religious norms that a regulation which comes from God, Norms Decency is the norm or rules that distinguish between good and not, as well as Norms Courtesy which is a rule that live in the community about the limits confines of decency or compliance.

As I got her life in this world makes the norms of living in society is often influenced by various interests, making what they should not become the norm and be advised in its implementation, as happened in the election of Regional Head in the elections this time, the possibility for the people who chose to give a mandate for former inmates considered that ex-prisoners also have human rights which should not be considered one eye and give the opportunity to become a better person by being a leader in the region. But for those who are not voting ex-convict would have to think differently, all return to the norms of life in the community.

\footnotetext{
${ }^{16}$ Soerjono Soekanto dan Purnadi Purbacaraka, 2005, Perihal Kaidah Hukum, PT Citra Aditya Bakti, Bandung, p. 06.

17 Esmi Warassih, 2005, Pranata Hukum Sebuah Telaah Sosiologis, Semarang, PT Suryandaru Utama, Semarang, p. 21.

18 Ibid, p. 29.

${ }^{19}$ Yuliandri, 2009, Asas-Asas Pembentukan Peraturan Perundang-Undangan Yang Baik, PT Raja Grafindo Persada, Jakarta, p. 21.
} 


\section{Closing}

\subsection{Conclusion}

- Normative Study of the relationship between Act No. 10 of 2016 by Government Regulation No. 151 of 2000 is Normative Act No. 10 of 2016 Jo. Act No. 12015 Jo. Act No. 1 of 2014 has a much higher position than the PP No. 151 of 2000, which is in line with the principle of Lex Superiori Derogat Lex Inferiori, namely the rule of law higher can cancel legal regulations below or lower, in other words regulations lower becomes invalid when it conflicts with a higher regulation thereon.

- A critical study of the relevance of Act No. 10 of 2016 with a norm of life in society are at canceled Article 7, paragraph 2 (g) of the Act No. 10 of 2016 by Constitutional Court Decision No. 42 / PUU-XIII / 2015 in accordance with the norms of life in society, in the implementation of the cancellation of the law should also be seen live in the community (living law).

\subsection{Suggestion}

There should be an institution in charge to synchronize the legislation so that the legislation does not contradict.

\section{Bibliography}

[1] Esmi Warassih, 2005, Pranata Hukum Sebuah Telaah Sosiologis, Semarang, PT Suryandaru Utama, Semarang.

[2] Ikhsan Rosyada Parhulutan Daulay, 2006, Mahkamah Konstitusi Memahami Keberadaanya Dalam Sistem Ketatanegaraan Indonesia, Rineka Cipta, Jakarta.

[3] Soerjono Soekanto dan Purnadi Purbacaraka, 2005, Perihal Kaidah Hukum, PT Citra Aditya Bakti, Bandung.

[4] Yadiman, 2011, Tehnik Pembuatan Perundangan, Cetakan Pertama, Badan Geologi.

[5] Yuliandri, 2009, Asas-Asas Pembentukan Peraturan Perundang-Undangan Yang Baik, PT Raja Grafindo Persada, Jakarta.

[6] Amar Constitutional Court Decision No. 42 / PUU-XIII / 2015

[7] Government Regulation No. 151 of 2000 on the Procedure for the Election, Validation, and Dismissal of Regional Head and Deputy Regional Head

[8] Act No. 04 Of 2014 Regarding The Determination of Government Regulation in Lieu of Act No. 1 of 2013 on the second amendment to Act No. 24 of 2003 on the Constitutional Court.

[9] Act No. 10 of 2016 on the second amendment to Act No. 1 of 2015 Concerning Determination of Government Regulation in Lieu of Act No. 1 of 2014 On the Election of governors, regents and mayors Become Law.

[10] Act No. 12 of 2011 Concerning the Establishment Regulation Legislation

[11] Act No. 23 of 2014 on Regional Government

[12] Act No. 7 of 2017 on General Election. 